Md. Jakaria*, Chayan Dhar Clinton, Mukimul Islam, Mohammad Belal Talukder, Md. Shariful Islam, Syed Mohammed Tareq and Shaikh Bokhtear Uddin

\title{
In vivo sedative and hypnotic activities of methanol extract from the leaves of Jacquemontia paniculata (Burm.f.) Hallier f. in Swiss Albino mice
}

DOI 10.1515/jbcpp-2016-0073

Received May 9, 2016; accepted October 11, 2016

\section{Abstract}

Background: The superior genus Jacquemontia belongs to Convolvulaceae, with around 120 species, and is also considered taxonomically difficult. The aim of this experiment was to assess the sedative and hypnotic activities of methanol extract from the leaves of Jacquemontia paniculata (Burm.f.) Hallier f.

Methods: The sedative and hypnotic activities were evaluated by hole-cross, open field, hole-board, elevated plus maze (EPM), and thiopental sodium-induced sleeping time determination tests in mice at doses of 200 and $400 \mathrm{mg} / \mathrm{kg}$.

Results: In this investigation, we found that methanol extract of Jacquemontia paniculata (MEJP) produced a significant dose-dependent inhibition of spontaneous activity of mice both in hole-cross and open field tests. In addition, it also decreased the number of head dips in hole-board test. In the case of EPM test, this crude extract induced an anxiogenic-like effect rather than anxiolytic effect in mice. Moreover, MEJP significantly decreased the induction time to sleep and prolonged the duration of sleeping, induced by thiopental sodium.

Conclusions: To conclude, these results suggest that the MEJP leaves possess potent sedative and hypnotic activities, which supported its therapeutic use for sleep disorders like insomnia.

Keywords: anxiogenic and insomnia; hypnotic; Jacquemontia paniculata; sedative.

\footnotetext{
*Corresponding author: Md. Jakaria, Department of Pharmacy, International Islamic University Chittagong (IIUC), Chittagong-4314, Bangladesh, E-mail: pharmajakaria@rocketmail.com Chayan Dhar Clinton, Mukimul Islam, Mohammad Belal Talukder and Md. Shariful Islam: Department of Pharmacy, International Islamic University Chittagong (IIUC), Chittagong-4314, Bangladesh Syed Mohammed Tareq: Department of Pharmacy, Southern University Bangladesh (SUB), Chittagong-4000, Bangladesh Shaikh Bokhtear Uddin: Department of Botany, University of Chittagong (CU), Chittagong-4331, Bangladesh
}

\section{Introduction}

Sleep disorders are a major public health issue for the reason that they have an important negative impact on an individuals' physical and social performance, their capacity to work, and their quality of life [1].

Anxiety is a condition of too much fear characterized by motor tension, apprehension, sympathetic hyperactivity and vigilance syndromes, leading to impairment of memory, intelligence, and psychological function [2].

Insomnia is defined as unquestionably the most widespread sleep disorder that includes difficulty in falling asleep, staying asleep, or waking too early, resulting in daytime impairment, which affects between 9\% and 15\% of the common population. It is influenced by a number of predisposing, precipitating and perpetuating factors, for instance, behavioral, biological, environmental, or psychological in nature [3, 4]. Insomnia is frequently comorbid with numerous psychiatric disorders including generalized anxiety, depression, bipolar, obsessive-compulsive, and post-traumatic stress disorder [4]. It can also subsist without other medical or mental health causes (primary insomnia). Long-standing (chronic) insomnia can lead to daytime consequences such as fatigue or sleepiness, difficulty with thinking, and mood impairments, which can interfere with performance at school and work [5].

Sedatives are drugs that decrease activity and have a calming, relaxing effect. When higher doses are administered to a patient, sedatives usually cause sleep. Hypnotics are used principally to cause sleep. The main difference between sedatives and hypnotics is typically the amount of the dose; lower doses have a calming effect on the contrary whereas higher doses cause sleep [6]. These drugs are expansively used in management of different psychiatric disorders including anxiety and insomnia [7]. Though, continuous use of these currently available sedative-hypnotic therapies tends to have serious side effects such as, respiratory, digestive, and immune system dysfunctions to deterioration of cognitive function, physical dependence, and tolerance [8]. Earlier studies have 
shown that herbal drugs produce good sedative and hypnotic effect on the central nervous system [9].

Convolvulaceae are known as a large family, comprising around 50-60 genera with some 1600-1700 species. Convolvulaceae exhibit a rich diversity of morphological characteristics and also occupy a broad range of ecological habitats. This large family is distributed throughout the world, and many species are dispersed in tropical ecosystems such as rain forests, savannas, prairies, and deserts [10, 11]. According to Pasha and Uddin (2013) in Bangladesh this family represents 87 species distributed in various parts of the country [12]. Previous reports revealed that different phytochemical active constituents such as flavonoids, terpenoids, phenols, and alkaloids may be present in Convolvulaceae species [13-17]. Several biological and pharmacological activities like neuro-pharmacological [18-22], antioxidant [15], antimicrobial [23], anti-inflammatory [24], and anti-diabetic [25] until now are detected in many species of the family Convolvulaceae.

Jacquemontia is one of the superior genera belonging to Convolvulaceae, with around 120 species, and also considered taxonomically difficult [26]. The family is eurypalynous and pollen morphology has been considered as an important taxonomic character [27]. Literature revealed that several flavonoids have been isolated and characterized from Jacquemontia pentantha and it has produced several biological activities like antioxidant, anti-hyperglycemic, and anti-inflammatory activities [26]. It is also reported that psychotomimetic ergot alkaloids has been detected in Jacquemontia tamnifolia [28]. Till now, the biological activities of many species of Jacquemontia along with biological, neuropharmacological activities and flavonoid components of Jacquemontia paniculata remain uninvestigated.

Regarding the previous reports on neuro-pharmacological activities of convolvulaceae, report on psychotomimetic activity of Jacquemontia pentantha along with reports on Jacquemontia tamnifolia, the aim of this experiment was to evaluate the sedative and hypnotic activities of the methanol extract of Jacquemontia paniculata (Burm.f.) Hallier f. (MEJP) leaves, and to, therefore, determine the scientific basis for its use in traditional medicine in the management of central nervous system disorders.

\section{Materials and methods}

\section{Plant material}

The leaves of J. paniculata were collected from Sitakunda thana of Chittagong district and it is authenticated by Professor Dr. Shaikh
Bokhtear Uddin, Department of Botany, University of Chittagong, Chittagong 4331, Bangladesh. A voucher specimen (JK-0127) of the plant sample has been preserved at the Chittagong University Herbarium (CTGUH) for future reference.

\section{Extraction of plant material}

The fresh leaves of $J$. paniculata were separated, washed, and air dried at room temperature $\left(24^{\circ} \mathrm{C} \pm 2{ }^{\circ} \mathrm{C}\right)$ for about 10 days. Then the leaves were ground into coarse powder $(250 \mathrm{~g})$ with a mechanical grinder (a Moulinex three-in-one grinder, Moulinex Corporation, Beijing, China). The coarse powder emerged using methanol and was shaken by rotary shaker apparatus for 7 days. The tincture was collected using Buckner funnel. Methanol was evaporated at a temperature below $45^{\circ} \mathrm{C}$ then $25 \mathrm{~g}$ of concentrated crude extract was weighed and stored at $4{ }^{\circ} \mathrm{C}$ temperature.

\section{Animals}

The male Swiss Albino mice weighing between 25 and $30 \mathrm{~g}$ were collected from the well-known animal laboratory of Jahangirnagar University (JU), Savar, Bangladesh. The animals were housed under suitable laboratory conditions (relative humidity 55\%-65\%, room temperature $23.0^{\circ} \mathrm{C} \pm 2.0^{\circ} \mathrm{C}$ and $12 \mathrm{~h}$ light: dark cycle) and acclimatized for 7 days. The animals were fed with proper diet and water.

\section{Phytochemical screening}

Freshly prepared crude methanol extract of leaves were dissolved in a suitable solvent and tested to screen the presence or absence of active phytochemical constituents such as carbohydrates, flavonoids, phenols, tannins, saponins, phytosterols, fixed oils, glycosides, and alkaloids by using standard phytochemical procedures [29-31].

\section{Selection of doses}

Before investigation in the mice, it was confirmed that the selected doses 200 and $400 \mathrm{mg} / \mathrm{kg}$ did not produce any toxicological symptom.

\section{Hole-cross test}

This test was conducted following the protocol described by Ali et al. [32]. In this experiment, a cage of a size of $30 \mathrm{~cm} \times 20 \mathrm{~cm} \times 14 \mathrm{~cm}$ with a fixed partition in the middle, and a hole of $3 \mathrm{~cm}$ diameter at a height of $7.5 \mathrm{~cm}$ in the center was used. Mice were treated with control, standard or extract then placed in one side of the cage and permitted to cross the hole from one chamber to another. The number of passage of a mouse through the hole from one chamber to another was counted for $3 \mathrm{~min}$ at $0,30,60,90$, and $120 \mathrm{~min}$ after the administration. Percentage of inhibition of movements was calculated by using the following formula:

Inhibition of movements (\%): mean no. of movements (control)

- mean no. of movements(test)/mean no. of movements(control) $\times 100$ 


\section{Open field test}

This method was carried out as per the procedure described by Gupta et al. [33]. The apparatus of the open field test consists of a wooden field of half square meter with a series of squares alternatively highlighted in black and white colors. It had a wall of $50 \mathrm{~cm}$ height and was placed in a dimly lit room. Mice were treated with control, standard or extract and then placed in the middle of the open field. Next, the number of squares visited by the animals was counted for $3 \mathrm{~min}$ at $0,30,60,90$, and 120 min after the treatments. Percentage inhibition of movements was calculated using the same formula used in hole-cross test.

\section{Hole-board test}

The hole-board test was performed according to the previously described method by Moniruzzaman et al. [7] and Alnamer et al. [9] with slight modifications. For this test, a perforated board was made by using a wood floor board, $40 \mathrm{~cm} \times 40 \mathrm{~cm} \times 25 \mathrm{~cm}$, which has evenly spaced holes. In brief, $30 \mathrm{~min}$ after control or extract and $15 \mathrm{~min}$ after diazepam administration, each animal was allowed to move on the platform and the number of head dips into the holes was counted for $5 \mathrm{~min}$.

\section{Elevated plus maze test}

The elevated plus maze test (EPM) test was performed following the method by Raihan et al. [34]. The apparatus consists of two open arms $(5 \mathrm{~cm} \times 10 \mathrm{~cm})$ and two closed arms $(5 \mathrm{~cm} \times 10 \mathrm{~cm} \times 15 \mathrm{~cm})$ radiating from a platform $(5 \mathrm{~cm} \times 5 \mathrm{~cm})$ to form a plus-sign figure. The apparatus was situated $40 \mathrm{~cm}$ above the floor. The open arms edges were $0.5 \mathrm{~cm}$ in height to keep the mice from falling and the closedarms edges were $15 \mathrm{~cm}$ in height. Sixty minutes after administration of the test drugs, each animal was individually placed in the center of the EPM and were allowed 5 min for free exploration. Next, the number of open and enclosed arm entries, and time spent on open arms were manually registered. Entry into an arm was defined as the point when the animal placed all four paws onto the arm.

\section{Thiopental sodium-induced sleeping time determination}

Thiopental sodium (TS)-induced sleeping time was also investigated according to the protocol described by Raihan et al. [34]. Thirty minutes after control or extract and 15 min after diazepam treatment, TS was administered to each animal through intraperitoneal route at the dose of $40 \mathrm{mg} / \mathrm{kg}$. After that, the animals were observed for the time to lose their righting reflex immediately after thiopental sodium injection (latent period) and the duration of sleep (time between the loss and recovery of reflex) induced by TS.

\section{Statistical analysis}

Data were expressed as mean \pm standard error of mean (SEM). Statistical comparisons were performed using one-way ANOVA followed by Tukey/Tukey-Kramer (equal/unequal observations). The values obtained were compared with the control group and considered statistically significant when $\mathrm{p}<0.001, \mathrm{p}<0.01$, and $\mathrm{p}<0.05$. All statistical analyses were performed using MaxStat Lite 3.60 version software.

\section{Ethical acceptance}

The study protocol was approved by the Planning and Development committee (Grant No. Pharmacy P\&D 68/09-15), Department of Pharmacy, International Islamic University Chittagong, Bangladesh.

\section{Results}

The results showed that MEJP exerts sedative and hypnotic effect on the central nervous system (CNS).

\section{Phytochemical screening}

Phytochemical screening of the leaves extract of J.paniculata confirmed the presence of carbohydrates, flavonoids, phenols, tannins, saponins, phytosterols, fixed oils, and glycosides.

\section{Hole-cross test}

The result verified that the oral administration of MEJP in all doses (200 and $400 \mathrm{mg} / \mathrm{kg}$ ) caused a noticeable reduction in the number of holes crossed. The exploitive statistical significant effect was found at 30 min and continued up to $120 \mathrm{~min}$ after administration of MJEP except at $90 \mathrm{~min}$ after administration of extract at $200 \mathrm{mg} / \mathrm{kg}$ (Table 1).

\section{Open field test}

Similar types of responses were observed as in the open field test. All tested doses produced significant inhibition of locomotion that was maintained between 30 and 120 min of observation period (Table 2).

\section{Hole-board test}

The experimental results exposed that the methanol extract of J.paniculata caused a dose-dependent reduction in head-dip response in the animals suggesting that the extract possesses sedative activity rather than anxiolytic 
Table 1: Effect of MEJP on hole-cross test.

\begin{tabular}{|c|c|c|c|c|c|c|}
\hline \multirow[t]{2}{*}{ Treatment } & \multirow[t]{2}{*}{ Dose, $\mathrm{mg} / \mathrm{kg}$} & \multicolumn{5}{|c|}{ Number of holes crossed (\% of inhibition) } \\
\hline & & $0 \mathrm{~min}$ & $30 \mathrm{~min}$ & $60 \mathrm{~min}$ & $90 \mathrm{~min}$ & $120 \mathrm{~min}$ \\
\hline Control & $1 \%$ Tween 80 in water & $14.20 \pm 0.37$ & $12 \pm 0.31$ & $12.8 \pm 0.37$ & $7.6 \pm 0.67$ & $14.40 \pm 0.24$ \\
\hline $\begin{array}{l}\text { Diazepam } \\
\text { (standard) }\end{array}$ & 50 & $\begin{array}{r}15 \pm 0.31 \\
(5.63)\end{array}$ & $\begin{array}{r}10.60 \pm 0.51 \\
(11.66)\end{array}$ & $\begin{array}{r}6 \pm 0.44^{\mathrm{a}} \\
(51.12)\end{array}$ & $\begin{array}{r}3.6 \pm 0.40^{\mathrm{b}} \\
(52.63)\end{array}$ & $\begin{array}{r}2.2 \pm 0.37^{\mathrm{a}} \\
(82.74)\end{array}$ \\
\hline MEJP & 200 & $\begin{array}{r}10 \pm 0.89^{b} \\
(28.57)\end{array}$ & $\begin{array}{r}8 \pm 1.22^{b} \\
(33.33)\end{array}$ & $\begin{array}{r}5 \pm 1.04^{\mathrm{a}} \\
(60.93)\end{array}$ & $\begin{array}{r}4.8 \pm 1.15 \\
(36.84)\end{array}$ & $\begin{array}{r}4.6 \pm 0.74^{\mathrm{a}} \\
(68.05)\end{array}$ \\
\hline MEJP & 400 & $\begin{array}{r}7.4 \pm 0.67^{\mathrm{a}} \\
(47.88)\end{array}$ & $\begin{array}{r}4.2 \pm 0.49^{b} \\
(65)\end{array}$ & $\begin{array}{r}1.2 \pm 0.49^{\mathrm{a}} \\
(90.62)\end{array}$ & $\begin{array}{r}0.6 \pm 0.24^{\mathrm{a}} \\
(92.10)\end{array}$ & $\begin{array}{l}0 \pm 0^{\mathrm{a}} \\
(100)\end{array}$ \\
\hline
\end{tabular}

Values are presented as mean \pm SEM $(n=5),{ }^{a} p<0.001,{ }^{b} p<0.01$ compared with the control group (one-way ANOVA followed by Tukey's test). MEJP, methanol extract of Jacquemontia paniculata.

Table 2: Effect of MEJP on open field test.

\begin{tabular}{|c|c|c|c|c|c|c|}
\hline \multirow[t]{2}{*}{ Treatment } & \multirow[t]{2}{*}{ Dose (mg/kg) } & \multicolumn{5}{|c|}{ Number of squares crossed (\% of inhibition) } \\
\hline & & $0 \mathrm{~min}$ & $30 \mathrm{~min}$ & $60 \mathrm{~min}$ & $90 \mathrm{~min}$ & $120 \mathrm{~min}$ \\
\hline Control & $1 \%$ Tween 80 in water & $102 \pm 0.31$ & $91 \pm 0.70$ & $82.60 \pm 0.51$ & $66.6 \pm 1.07$ & $51.20 \pm 0.58$ \\
\hline $\begin{array}{l}\text { Diazepam } \\
\text { (standard) }\end{array}$ & 1 & $\begin{array}{r}98.8 \pm 1.53^{\mathrm{a}} \\
(3.13)\end{array}$ & $\begin{array}{r}31.60 \pm 0.92^{\mathrm{b}} \\
(61.7)\end{array}$ & $\begin{array}{r}26.40 \pm 0.51^{a} \\
(60.34)\end{array}$ & $\begin{array}{r}17 \pm 0.70^{\mathrm{a}} \\
(66.79)\end{array}$ & $\begin{array}{r}11.80 \pm 3.74^{\mathrm{a}} \\
(77.98)\end{array}$ \\
\hline MEJ & 200 & $\begin{array}{r}98.20 \pm 0.37^{\mathrm{a}} \\
(3.72)\end{array}$ & $\begin{array}{r}81.20 \pm 0.58^{\mathrm{a}} \\
(1.69)\end{array}$ & $\begin{array}{r}62.20 \pm 0.86^{a} \\
(6.6)\end{array}$ & $\begin{array}{r}32 \pm 0.89^{\mathrm{a}} \\
(37.5)\end{array}$ & $\begin{array}{r}26 \pm 0.89^{\mathrm{a}} \\
(51.49)\end{array}$ \\
\hline MEJ & 400 & $\begin{array}{r}96 \pm 0.89^{\mathrm{a}} \\
(5.88)\end{array}$ & $\begin{array}{r}69.40 \pm 3.37^{\mathrm{a}} \\
(15.98)\end{array}$ & $\begin{array}{r}26.40 \pm 1.12^{\mathrm{a}} \\
(60.36)\end{array}$ & $\begin{array}{r}16.40 \pm 1.16^{\mathrm{a}} \\
(67.98)\end{array}$ & $\begin{array}{r}8.80 \pm 0.58^{\mathrm{a}} \\
(83.58)\end{array}$ \\
\hline
\end{tabular}

Values are presented as mean \pm SEM $(n=5),{ }^{a} p<0.001,{ }^{b} p<0.05$ compared with the control group (one-way ANOVA followed by Tukey's test). MEJP, methanol extract of Jacquemontia paniculata.

potentials. The observed effects in the treated groups were statistically significant $(\mathrm{p}<0.001)$ when compared with the control group (Table 3).

\section{EPM test}

The methanol extract of $J$. paniculata induced an anxiogenic-like effect in mice, as it increased closed arm entries

Table 3: Effect of MEJP on hole-board test.

\begin{tabular}{llrr}
\hline Treatment & $\begin{array}{l}\text { Dose } \\
(\mathbf{m g} / \mathbf{k g})\end{array}$ & \begin{tabular}{r} 
Responses \\
\cline { 3 - 4 }
\end{tabular} & $\begin{array}{l}\text { Number of head dipping } \\
\text { \% Inhibition }\end{array}$ \\
\hline Control & $\begin{array}{l}\text { 1\% Tween } \\
80 \text { in water }\end{array}$ & $41 \pm 0.70$ & 0 \\
Diazepam & 1 & $29.6 \pm 0.93^{\mathrm{a}}$ & $38.51 \%$ \\
(standard) & & & \\
MEJP & 200 & $18.40 \pm 0.51^{\mathrm{a}}$ & $56.09 \%$ \\
MEJP & 400 & $13.20 \pm 0.66^{\mathrm{a}}$ & $68.29 \%$ \\
\hline
\end{tabular}

Values are presented as mean \pm SEM $(n=5)$, ${ }^{a} p<0.001$ compared with the control group (one-way ANOVA followed by Tukey's test). MEJP, methanol extract of Jacquemontia paniculata. and the time spent in the closed arms of the EPM when compared to the control animals (Table 4).

\section{Thiopental sodium-induced sleeping time determination}

In our investigation, the oral treatment with 100 , and $200 \mathrm{mg} / \mathrm{kg}$ of MEJP 30min before the TS injection significantly modified the latency to induce sleep as well as increasing the duration of hypnosis induced by TS. As expected, similar types of effects were observed by the administration with diazepam at a dose of $1 \mathrm{mg} / \mathrm{kg}$ (Table 5).

\section{Discussion}

The present study investigated the putative CNS effect of methanol extract from the leaves of J. paniculata. Diazepam is a very familiar anxiolytic benzodiazepine which produces anxiolytic as well as sedative action. It was used as a standard drug to compare with the extract. 
Table 4: Effect of the MEJP leaves on the number of entries and time spent in open and closed arm in elevated maze test.

\begin{tabular}{llrrrr}
\hline Treatment & Dose $(\mathrm{mg} / \mathrm{kg})$ & & & Responses \\
\cline { 3 - 6 } & & $\begin{array}{r}\text { No. of open } \\
\text { arm entries }\end{array}$ & $\begin{array}{r}\text { Time spent in } \\
\text { open arm (s:ms) }\end{array}$ & $\begin{array}{r}\text { No. of closed } \\
\text { arm entries }\end{array}$ & $\begin{array}{r}\text { Time spent in } \\
\text { closed arm (s:ms) }\end{array}$ \\
\hline Control & $1 \%$ Tween 80 in water & $0.40 \pm 0.49$ & $1.20 \pm 0.49$ & $2.2 \pm 0.49$ & $286.80 \pm 2.17$ \\
Diazepam & 50 & $5.20 \pm 0.37^{\mathrm{b}}$ & $35.40 \pm 2.48^{\mathrm{b}}$ & $19.20 \pm 1.15^{\mathrm{a}}$ & $216.2 \pm 4.1^{\text {a }}$ \\
(standard) & & & & & \\
MEJP & 200 & $1.6 \pm 0.67$ & $18.72 \pm 7.64$ & $4.4 \pm 0.24$ & $275.9 \pm 9.69^{\mathrm{b}}$ \\
MEJP & 400 & $3.8 \pm 1.39$ & $46.33 \pm 8.33^{\mathrm{a}}$ & $6.8 \pm 2.37$ & $247.35 \pm 9.36$ \\
\hline
\end{tabular}

Values are presented as mean \pm SEM $(n=5),{ }^{a} p<0.001,{ }^{b} p<0.01$ compared with the control group (one-way ANOVA followed by Tukey’s test). MEJP, methanol extract of Jacquemontia paniculata.

Table 5: Effect of MEJP on thiopental sodium-induced sleeping time.

\begin{tabular}{llrr}
\hline Treatment & Dose $(\mathrm{mg} / \mathrm{kg})$ & & Responses \\
\cline { 3 - 3 } & & Onset of sleeping (min:s) & Sleeping duration (min:s) \\
\hline Control & $1 \%$ Tween 80 in water & $39 \pm 07$ & $45.80 \pm 0.73$ \\
Diazepam (standard) & 1 & $11.60 \pm 0.51^{\mathrm{a}}$ & $142 \pm 0.70^{\mathrm{a}}$ \\
MEJP & 200 & $11.72 \pm 0.17^{\mathrm{a}}$ & $70.40 \pm 3.42^{\mathrm{a}}$ \\
MEJP & 400 & $3.60 \pm 0.24^{\mathrm{a}}$ & $84 \pm 0.44^{\mathrm{a}}$ \\
\hline
\end{tabular}

Values are presented as mean \pm SEM $(n=5)$, ${ }^{a} p<0.001$ compared with the control group (one-way ANOVA followed by Tukey's test). MEJP, methanol extract of Jacquemontia paniculata.

The hole-cross and open field tests have been conducted by recording spontaneous locomotor activity of mice to elucidate the sedative effects of MEJP. In both tests, any agent with sedative properties will cause a decrease in the number of movements, interpreted as a decrease in curiosity of the new environment $[35,36]$. This ability of MEJP to suppress the locomotor activity suggests that the extract is endowed with central nervous system depressant activity similar to the diazepam.

Another important observation was achieved in the hole-board test. This test is well established as a means to examine potential anxiolytic and sedative effects of any agents by observing the exploratory behavior in experimental animals. This experiment is beneficial due to its methodological simplicity and several behavioral responses of an animal can be voluntarily observed and quantified when exposed to an unfamiliar environment. The head-dipping behavior of the animals is directly connected to their emotional state [37]. It was recommended that the expression of an anxiolytic state in animals might be reflected by an increase in head-dipping behavior, while a decrease in the number of head dips was found to be interrelated with the depressant effect [38, 39]. Regarding this experimental result, this extract produced sedative effect rather than anxiolytic effect in the hole-board test.
The EPM is one of the most widely validated tests and is highly sensitive to the influence of both anxiolytic and anxiogenic drugs acting at the gamma aminobutyric acid type A (GABAA)-benzodiazepine complex [40]. In EPM, normal mice will normally wish to spend much of their allotted time in the closed arms and this preference appears to reflect an aversion towards open arms that is generated by the fears of the open spaces. Bendiazepines like diazepam that increases open arm exploration are considered as anxiolytic and the reverse holds true for anxiogenics [41]. In this experiment, this extract showed anxiogenic effect that was comparable to the anxiogenic drugs.

The above-described findings were further supported by the results observed in thiopental sodium-induced sleeping time determination test. This test is a classical method in behavioral pharmacology to investigate the sedative and hypnotic properties. Glutamate and GABA are quantitatively the most vital excitatory and inhibitory neurotransmitters, respectively, in the mammalian brain and these two neurotransmitters are regarded as important targets for psychotropic drugs [9, 42]. The inhibitory action of GABA consists in the opening of chloride channels to permit hyperpolarizing the membrane, leading to CNS depression and resulting in sedative and hypnosis activity [9]. Considerable evidence showed that the CNS 
depressant barbiturates, such as TS, bind to the barbiturate binding site on the GABA receptor complex and potentiate GABA-mediated hyperpolarization of postsynaptic neurons [43]. Based on our results we recommend that there might be a relationship between the sedative effect produced by MEJP and the sedation inductive capacity of diazepam. Consequently, it is possible that the GABAergic system may participate in the MEJP-induced enhancement of the effects of TS. In the thiopental-induced sleeping test in mice, the potentate effect of J. paniculata extract in mice was represented.

Various studies revealed that different active components such as coumarin, chalcones, flavanones, flavones, flavonols, quercetin, and kaempferol derivatives are mainly responsible for sedative and hypnotic activities [7, 9, 44-46]. Our study confirmed that, glycosides, phenols, and flavoinds were present in the crude extract. Hence, these types of phytochemical active constituents may be responsible for sedative and hypnotic activities. Further chemical and pharmacological analysis of the extract should be conducted to isolate and characterize the active principles responsible for the sedative and hypnotic effect.

In conclusion, the exploratory behavior pattern and spontaneous activities of the methanol extracts of J. paniculata in mice model have sedative and hypnotic activities; our data provide a pharmacological basis for its therapeutic efficacy on insomnia. Further research of this plant might contribute to the field of neurology as herbal or/and allopathic drugs to treat sleep disorders.

Acknowledgments: The authors thank the authorities of the Department of Pharmacy, International Islamic University Chittagong for providing valuable laboratory facilities.

Author contributions: All the authors have accepted responsibility for the entire content of this submitted manuscript and approved submission. MJ, CDC, MI, MBT, and MSI designed and conducted the experiments under the supervision of SBU. MJ, SMT, and SBU wrote the manuscript and analyzed the data. MJ also edited and drafted the manuscript. All authors read and approved the final manuscript.

Research funding: None declared.

Employment or leadership: None declared.

Honorarium: None declared.

Competing interests: The funding organization(s) played no role in the study design; in the collection, analysis, and interpretation of data; in the writing of the report; or in the decision to submit the report for publication.

\section{References}

1. El-Tantawya AM, Al-Yahya A, Raya YM, Mohamed SA. Sleep disorders and sleep quality among patients with anxiety or depressive disorders in relation to their quality of life. Egyptian J Psychiatr 2014;35:56-64.

2. Sampath TS, Santosh P, Lahkar M, Ajaygodwin P, Kumar SP, Lingesh A. Anxiolytic effect of ethanolic extract of Oxalis corniculata. L in mice. Int J Pharm Bio Sci 2011;2:281-90.

3. Spielman AJ, Caruso L, Glovinsky PB. A behavioural perspective on insomnia treatment. Psychiatr Clin North Am 1987;10:541-3.

4. Akram U, Ellis JG, Barclay NL. Anxiety mediates the relationship between perfectionism and insomnia symptoms: a longitudinal study. PLoS One 2015;10:e0138865.

5. Ford DE, Kamerow DB. Epidemiologic study of sleep disturbances and psychiatric disorders, an opportunity for prevention. J Am Med Assoc 1989;262:1479-84.

6. Huang F, Xiong Y, Xu L, Ma S, Dou C. Sedative and hypnotic activities of the ethanol fraction from Fructus Schisandrae in mice and rats. J Ethnopharmacol 2007;110:471-5.

7. Moniruzzaman M, Rahman MA, Ferdous A. Evaluation of sedative and hypnotic activity of ethanolic extract of Scoparia dulcis Linn. Evidence-Based Comp Alter Med 2015;2015:873954.

8. Dhawan K, Dhawan S, Chhabra S. Attenuation of benzodiazepine dependence in mice by a tri-substituted benzoflavone moiety of Passiflora incarnata Linneaus: a non-habit forming anxiolytic. J Pharm Pharm Sci 2003;6:215-22.

9. Alnamer R, Alaoui K, Bouidida EH, Benjouad A, Cherrah Y. Sedative and hypnotic activities of the methanolic and aqueous extracts of Lavandula officinalis from Morocco. Adv Pharmacol Sci 2012;2012:270824.

10. Stefanović S, Krueger L, Olmstead RG. Monophyly of the convolvulaceae and circumscription of their major lineages based on DNA sequences of multiple chloroplast loci. Am J Bot 2002;8:1510-22.

11. Silva FO, Kevan SD, Roque N, Viana BF, Kevan PG. Records on floral biology and visitors of Jacquemontia montana (Moric.) Meisn. (Convolvulaceae) in Mucugê, Bahia. Braz J Biol 2010;70:671-6.

12. Pasha MK, Uddin SB. Dictionary of plant names of Bangladesh (vascular plants). Chittagong, Bangladesh: Janokalyan Prokashoni, 2013:433.

13. Jalaj AV, Radhamany PM. Pharmacognostic studies on leaf of Operculina turpethum (L.) Silva Manso. Int J Adv Res 2014;2:585-90.

14. Venkataraman ND, Atlee WC, Prabhu TP, Kannan R. Antiinflammatory potential of ethanolic extracts from aerial parts of Ipomoea Pes-Caprae (L.) R.Br using cotton pellet induced granuloma model. J Appl Pharm Sci 2013;3:61-3.

15. Matunog VE, Bajo LM. Phytochemical screening and antioxidative potentials of "Beach Morning Glory" Ipomoea pes-caprae (Linn.) Roth leaves extract. J Multidisciplinary Stud 2013;1:1-18.

16. Abu-Dahab R, Afifi F. Antiproliferative activity of selected medicinal plants of Jordan against a breast adenocarcinoma cell line (MCF7). Sci Pharma 2007;75:121-36.

17. Essiett UA, Ukpong UJ. Comparative phytochemical, nutrient and anti-nutrient of stems of Ipomoea involucrata Beauv, Ipomoea. Triloba L. and Ipomoea Batatas Lam. Am J Food Nutr 2014;2:71-6.

18. Siddiqui NA, Ahmad N, Musthaq N, Chattopadhyaya I, Kumria R, Gupta S. Neuropharmacological profile of extracts of aerial parts 
of Convolvulus pluricaulis Choisy in mice model. Open Neurol J 2014;8:11-14.

19. Chakma TK, Mth K, Rahman T, Choudhuri MS, Rajia S, Alamgir M. Analisis de los efectos de plantas medicinales de Bangladesh en la duracion del sueno inducido por pentobarbital en ratones. Ars Pharm 2006;47:211-17.

20. Galani VJ, Patel BG. Central nervous system activity of Argyreia speciosa roots in mice. Res J Pharm Tech 2009;2:331-4.

21. Bihaqi SW, Singh AP, Tiwari M. In vivo investigation of the neuroprotective property of Convolvulus pluricaulis in scopolamine-induced cognitive impairments in Wistar rats. Indian J Pharmacol 2011;43:520-5.

22. Dasari P, Chennamaneni SR, Reddy H, Challa S. Neuropharmacological effects of aqueous and ethanolic extracts from the roots of Operculina turpethum in Swiss albino mice. J Adv Pharma Sci 2012;2:303-14.

23. Panaccione DG. Origins and significance of ergot alkaloid diversity in fungi. FEMS Microbiol Lett 2005;251:9-17.

24. Ferreira AA, Amaral FA, Duarte ID, Oliveira PM, Alves RB, Silveira $D$, et al. Antinociceptive effect from Ipomoea cairica extract. J Ethnopharmacol 2006;105:148-53.

25. Malalavidhane S, Wickramasinghe SM, Jansz ER. An aqueous extract of the green leafy vegetable Ipomoea aquatica is as effective as the oral hypoglycaemic drug tolbutamide in reducing the blood sugar levels of Wistar rats. Phytother Res 2001;15:635-7.

26. Nassar MI, Aboutabl EA, Eskander DM, Grace MH, Aty AA, Sleem $A A$, et al. A new acylated flavonol triglycoside and bioactivities of Jacquemontia pentantha (Jacq.). Res J Pharma Bio Chem Sci 2015;6:677-86.

27. Buril MT, Oliveira PP, Rodrigues R, Santos FA, Alves M. Pollen morphology and taxonomic implications in Jacquemontia Choisy (Convolvulaceae). Grana 2015;54:1-11.

28. Wilkinson RE, Hardcastle WS, McCormick CS. Psychotomimetic ergot alkaloid contents of seed from Calonyction muricatum, Jacquemontia tamnifolia, Quamoclit lobata and Q. sloteri. Bot Gaz 1988;149:107-9.

29. Ugochukwu SC, Uche IA, Ifeanyi O. Preliminary phytochemical screening of different solvent extracts of stem bark and roots of Dennetia tripetala G. Baker. Asian J Plant Sci Res 2013;3:10-13.

30. Suganya RS, Priya K, Roxy BS. Phytochemical screening and antibacterial activity from Nerium oleander and evaluate their plant mediated nanoparticle synthesis. Int Res J Pharm 2012;3:285-8.

31. Savithramma N, Linga Rao M, Suhrulatha D. Screening of medicinal plants for secondary metabolites. Middle-East J Sci Res 2011;8:579-84.

32. Ali MS, Dash PR, Nasrin M. Study of sedative activity of different extracts of Kaempferia galanga in Swiss albino mice. BMC Comp Alter Med 2015;15:158.
33. Gupta BD, Dandiya PC, Gupta ML. A psychopharmacological analysis of behaviour in rats. Jpn J Pharmacol 1971;21:293-8.

34. Raihan MO, Habib MR, Brishti A, Rahman MM, Saleheen MM, Manna M. Sedative and anxiolytic effects of the methanolic extract of Leea indica (Burm. f.) Merr. Leaf. Drug Dis Ther 2011;5:185-9.

35. Takagi K, Watanabe M, Saito H. Studies of the spontaneous movement of animals by the hole cross test; effect of 2-dimethyl-aminoethanol and its acyl esters on the central nervous system. Jpn J Pharmacol 1971;21:797-810.

36. Prut $L$, Belzung $C$. The open field as a paradigm to measure the effects of drugs on anxiety-like behaviors: a review. Eur J Pharmacol 2003;463:3-33.

37. Takeda H, Tsuji M, Matsumiya T. Changes in head dipping behavior in the hole-board test reflect the anxiogenic and/or anxiolytic state in mice. Eur J Pharmacol 1998;350:21-9.

38. File SE, Pellow S. Intrinsic actions of the benzodiazepine receptor antagonist, Ro 15-1788. Psychopharmacology 1986;88:1-11.

39. Viola H, Wasowski C, Levi de Stein M, Wolfman C, Silveira R, Dajas F, et al. Apigenin, a component of Matricaria recutita flowers, is a central benzodiazepine receptors-ligand with anxiolytic effects. Plant Med 1995;61:213-16.

40. Sharmen F, Mannan A, Rahman MM, Chowdhury MA, Uddin ME, Ahmed AM. Investigation of in vivo neuropharmacological effect of Alpinia nigra leaf extract. Asian Pacific J Trop Biomed 2014;4:137-42.

41. Subramanian N, Jothimanivannan C, Kumar RS, Kameshwaran S. Evaluation of anti-anxiety activity of Justicia gendarussa burm. Pharmacology 2013;4:404-7.

42. Schousboe A, Bak LK, Waagepetersen HS. Astrocytic control of biosynthesis and turnover of the neurotransmitters glutamate and GABA. Front Endocrinol (Lausanne) 2013;4:102.

43. Fernandez S, Wasowski C, Paladini AC, Marder M. Sedative and sleep-enhancing properties of linarin, a flavonoidisolated from Valeriana officinalis. Pharmacol Biochem Behav 2004;77:399-404.

44. Huang F, Xiong Y, Xu L, Ma S, Dou C. Sedative and hypnotic activities of the ethanol fraction from Fructus schisandrae in mice and rats. J Ethnopharmacol 2007;110:471-5.

45. Pérez-Ortega G, Guevara-Fefer P, Chávez M, Herrera J, Martínez A, Martínez AL, et al. Sedative and anxiolytic efficacy of Tilia americana var. mexicana inflorescences used traditionally by communities of State of Michoacan, Mexico. J Ethnopharmacol 2010;116:461-8.

46. Zapata-Sudo G, Mendes TC, Kartnaller MA, Fortes TO, Freitas NF, Kaplan MA, et al. Sedative and anticonvulsant activities of methanol extract of Dorstenia arifolia in mice. J Ethnopharmacol 2010;130:9-12. 